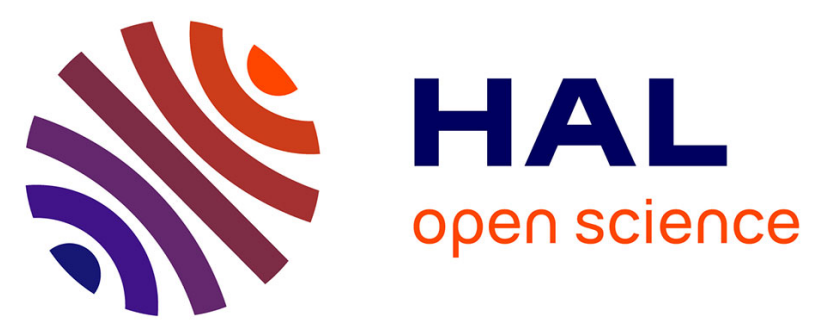

\title{
Knowledge Use in Education for Environmental Citizenship-Results of Four Case Studies in Europe (France, Hungary, Serbia, Turkey)
}

Imre Kovách, Boldizsár Gergely Megyesi, Angela Barthes, Hasan Volkan Oral, Marija Smederevac-Lalic

\section{To cite this version:}

Imre Kovách, Boldizsár Gergely Megyesi, Angela Barthes, Hasan Volkan Oral, Marija SmederevacLalic. Knowledge Use in Education for Environmental Citizenship-Results of Four Case Studies in Europe (France, Hungary, Serbia, Turkey). Sustainability, 2021, 13, 10.3390/su131911118 . hal03537787

\section{HAL Id: hal-03537787 \\ https://hal.science/hal-03537787}

Submitted on 20 Jan 2022

HAL is a multi-disciplinary open access archive for the deposit and dissemination of scientific research documents, whether they are published or not. The documents may come from teaching and research institutions in France or abroad, or from public or private research centers.
L'archive ouverte pluridisciplinaire HAL, est destinée au dépôt et à la diffusion de documents scientifiques de niveau recherche, publiés ou non, émanant des établissements d'enseignement et de recherche français ou étrangers, des laboratoires publics ou privés.

\section{(c)(1)}

Distributed under a Creative Commons Attribution| 4.0 International License 
See discussions, stats, and author profiles for this publication at: https://www.researchgate.net/publication/355168567

\section{Knowledge Use in Education for Environmental Citizenship-Results of Four Case Studies in Europe (France, Hungary, Serbia, Turkey)}

Article in Sustainability · October 2021

DOI: $10.3390 /$ su131911118

CITATIONS

0

5 authors, including:

Imre Kovách

Hungarian Academy of Sciences

62 PUBLICATIONS 679 CITATIONS

SEE PROFILE

Angela Barthes

Aix-Marseille Université

98 PUBLICATIONS 608 CITATIONS

SEE PROFILE
READS

45

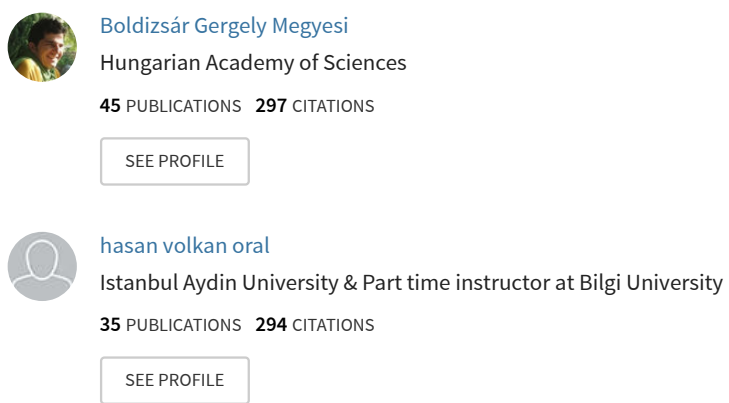

Some of the authors of this publication are also working on these related projects:

Analyse statistiques des données en sciences humaines économiques et sociales View project

EduBioMed : DÉVELOPPEMENT DES COMPÉTENCES POUR L’ÉDUCATION ET LA RECHERCHE APPLIQUÉE DANS LES RÉSERVES DE BIOSPHÈRE MÉDITERRANÉENNE DE L'UNESCO Said Boujrouf View project 
Article

\title{
Knowledge Use in Education for Environmental Citizenship - Results of Four Case Studies in Europe (France, Hungary, Serbia, Turkey)
}

\author{
Imre Kovách 1,2, Boldizsár Gergely Megyesi 1,*, Angela Barthes ${ }^{3}$, Hasan Volkan Oral ${ }^{4}$ and \\ Marija Smederevac-Lalic ${ }^{5}$ \\ 1 Institute for Sociology, Centre for Social Sciences, Hungarian Academy of Sciences, Tóth Kálmán u. 4, \\ 1097 Budapest, Hungary; kovach.imre@tk.hu \\ 2 Department of Sociology and Social Policy, University of Debrecen, Egyetem tér 1., 4032 Debrecen, Hungary \\ 3 Apprentissages, Didactiques, Evaluation, Formation, Department of Education in Social Sciences, \\ Humanities and Management, Aix-Marseille University, 13007 Marseille, France; \\ angela.barthes@univ-amu.fr \\ 4 Department of Civil Engineering, Faculty of Engineering, İstanbul Aydın University, Istanbul 34295, \\ Turkey; volkan.oral@gmail.com \\ 5 Institute for Multidisciplinary Research, University of Belgrade, 11000 Belgrade, Serbia; \\ marijasmederevac@imsi.bg.ac.rs \\ * Correspondence: Megyesi.Boldizsar@tk.mta.hu
}

Citation: Kovách, I.; Megyesi, B.G.; Barthes, A.; Oral, H.V.; Smederevac-Lalic, M. Knowledge Use in Education for Environmental Citizenship-Results of Four Case Studies in Europe (France, Hungary, Serbia, Turkey).

Sustainability 2021, 13, 11118.

https://doi.org/10.3390/su131911118

Academic Editor: Ralph Hansmann

Received: 3 August 2021

Accepted: 30 September 2021

Published: 8 October 2021

Publisher's Note: MDPI stays neutral with regard to jurisdictional claims in published maps and institutional affiliations.

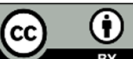

Copyright: $@ 2021$ by the authors. Licensee MDPI, Basel, Switzerland. This article is an open access article distributed under the terms and conditions of the Creative Commons Attribution (CC BY) license (http://creativecommons.org/licenses/by/4.0/).

\begin{abstract}
The aim of the paper is to contribute to the research on education for environmental citizenship in a comparative perspective. The central concept of education is the complex issue of knowledge. In the present paper, different knowledge forms, knowledge use, and types of knowledge production in environmental education are analysed for two EU countries, France and Hungary, together with two candidate countries, Serbia and Turkey. We review the most important theories and publications, the research questions and the methods considered to be examples for our present work. The second part of the paper presents the case studies according to the theoretical priorities. Evidence-based papers on cases in different European countries illustrating and discussing the evaluation of the types of knowledge used in environmental education and sustainability projects, as well as analysing the power-related components of knowledge use are reviewed. In the final part, case studies are compared and conclusions are drawn.
\end{abstract}

Keywords: education; environmental citizenship; knowledge; power relations; cross-country comparison

\section{Introduction}

The use of knowledge is a central issue in environmental discourse, highlighting whose knowledge determines the direction of environmental practices in education, policy decisions, local development, and the economy. The functioning of power is perhaps most clearly understood through the assertion of the types of knowledge that permeates all relevant components of environmental citizenship, from the formation of environmental education and attitudes to the details of resource allocation and practical activities. The detection and management of environmental hazards has always triggered the activities of groups of different actors who have had unequal access to the production, use, and validation of the necessary knowledge. Indigenous, tacit knowledge is mostly subordinated to environmental doctrines worked out and accepted in organizations. The mobilization capacity of NGOs and state or international bureaucratic institutions require a different kind of knowledge capital. Hadjichambis et al. [1] highlighted that key concepts 
and practices can affect a wide variety of scientific, advocacy, economic, and political arenas, just as green political thinking can be saturated with conflicting moral values [2]. The practice-oriented nature of intervention, prevention, and mobilization focuses on something other than the ethically determined values of autonomous provision and locality [3].

Environmental education and education for environmental citizenship, as defined by Hadjichambis et al. [1] are a particularly special field for the symbolic and practical clashes of competing ideas, interests, and organizations. Smederevac-Lalic et al. [4] explain that formal, informal, and non-formal education are mediators of other types of knowledge and that the perceptions and interests of participants in the three organizational forms also express different intentions and aspirations.

The aim of this paper is to show, with four cases of environmental education (French, Hungarian, Serbian, and Turkish), what forms of organizations are created in practice for the production and transfer of knowledge related to Environment Citizenship. The source of growing complexity is what kind of aspirations and ideas are the main drivers of formal and informal education, which is the focus of our work together with the neglected subject of power relations. The structure of the paper is as follows. Following the introductory part, the second includes a review of the most important concepts and publications, and the third includes the research questions and methods. In the fourth part, we describe the cases of environmental education, divided into four subchapters. The discussion chapter summarizes the evidence for comparing the four cases, and finally conclusions are drawn.

\section{Theoretical Background}

A summarizing study [4] clearly points out that environmental education is successful if it can combine the use of a wide variety of types of knowledge in specific organizational forms that "assist in the application of environmental ethics in every human activity" [4] (p. 80). Environmental knowledge is naturally interdisciplinary, and its utilization is beneficial if it incorporates the benefits of several types of knowledge.

Scientific knowledge is mainly explicit, well documented, institutionalized and sequential [5,6]. While scientific knowledge presents embracing theories and concepts, based on proven and excepted scholarly methods supported by a systematic collection of information from different localities and situations, local knowledge is specific, based on experiences and sometimes irregular observations. Scientific knowledge can be used locally if it is adjusted to the local environment and refined based on local experiences; thus local and scientific knowledge supplement each other. Local knowledge is most useful if it is combined with other knowledge forms, although it can be valuable in itself, such as, for example, when managing socio-ecological systems [7,8].

As mentioned above, local knowledge is informal, simultaneous, often tacit, and based on experiences [5,6]. Local knowledge sometimes overlaps with traditional knowledge, although the dynamics of succession of these types is different [9]. In addition, the terms traditional ecological knowledge, indigenous knowledge or science, folk knowledge, farmers' knowledge, fishers' knowledge, and tacit knowledge shall be classified as local knowledge.

A third knowledge form defined in previous research on knowledge used in local development is managerial knowledge. Its emergence is linked to the project class phenomenon [10,11]. Managerial knowledge refers to financial and administrative knowledge, e.g., project writing and management skills [5]. According to the literature, managerial knowledge is explicit, specialised and learned in educational institutions. However, it can also be informal, experiential, and person-bound [5]. Although it has sitespecific elements, it is always rooted in wider institutional and economic environment. It plays an important role in the projectified society [11,12]; thus it became one of the most important forms of knowledge, and it is necessary to analyse it more deeply.

Citizen science has gained popularity, as it offers to close or at least tighten the gap between science and society [13]. It has various forms, from engaging individuals or communities to the whole process of knowledge production to using them as data sources. 
The analysis of education for environmental citizenship initiatives can be interesting from this point of view, because these could be built on local knowledge per se and also show the force of inclusion. Thus, it builds on an existing knowledge and provides a real world example of how a democratic process can evolve; this way power relations are also an important part of the analysis.

Knowledge use encompasses the bottom-up and participatory approach [4], which, according to research experience, can be safely supplemented with top-down knowledge transfers. None of the ways of using knowledge takes place in a social vacuum; in practice, individual and institutional interests, as well as the operational rationality of projects and bureaus, mean that the moral commitments of the participants all affect environmental knowledge, modifying, strengthening, or even weakening its effectiveness.

Among the possible dimensions of research on knowledge use in environmental citizenship, the issue of power certainly has an important function. As the study of Levinson et al. [14] explains, the nature and intervention of political power can primarily influence the use of knowledge between human beings and the environment. As an example, the libertarian [15] and communitarian [16] orderly societies are mentioned, whose dominant ideological perspectives (referring to Dobson's [17] division of environmentalism versus ecologism) clearly determine the content of environmental citizenship. Political power can have strong control over the school system, which has a prominent role to play, but also over the definition of themes and values of out-of-school knowledge transfer, the formalization of education, and access to the necessary resources. The work of Levinson et al. [15] underscores the role of key players and, based on Johnson and Morris [18], describes the ideal types of environment citizen as the personally responsible, participative, and socially responsible ideal types, not forgetting that not only individuals but also institutions, and above all the state, can also be key players. Csurgó et al. [19] recommend a joint analysis of the use of knowledge types and power (project) networks for a more accurate interpretation, a method we will use in our paper.

\section{Research Questions and Methods}

In our paper, we seek to reveal the different knowledge forms appearing in environmental education by comparing France, representing Western Europe, and an old member state of the EU; Hungary, representing Central Eastern Europe, and a new member state of the EU; Serbia, an Eastern European country, and Turkey, both candidate countries of EU membership. According to the reviewed literature the differences in knowledge use and forms of knowledge production in environmental education also mirror the characteristic power relations of environmental education. We analysed the different forms of environmental education to grasp its diversity: the French case focuses on the knowledge used in environmental education in formal higher education, the Hungarian case focuses on non-formal elementary education, the Serbian case analyses the knowledge use in formal elementary education, while the Turkish case again is focused on formal higher education.

By bringing together the four cases, we aim to answer the following questions:

1. What is the role of environmental education and education for environmental citizenship in the analysed cases?

2. What are the main forms of knowledge represented and used in environmental education?

3. How are power relations represented in education for environmental citizenship?

4. How do power relations influence environmental education?

To answer the above questions we used mainly secondary analysis of existing statistical data, the review of case studies, grey literature, and other existing documents of the institutions where the case studies were conducted. For each country, we prepared a first version of the analysis using the above described methods to reveal knowledge use and 
power relations, and we prepared a case-study based on additional semi structured interviews with experts and activists from the field. The activists were mostly teachers or members of civic associations but were sometimes officials [20,21].

\section{Methodology}

Our analysis is based on published literature about EE, semi-structured interviews with experts in the field of education, and the results of a common questionnaire conducted for a SWOT Analysis on Education for Environmental Citizenship [1]. We used a common framework for the secondary analysis of the case studies in each country to understand knowledge use and power relations in EE. We chose for each country the best examples of the case studies to demonstrate the contextualised implementation of the environmental education in practice. The country-specific methodological descriptions are as follows:

The analyses curricular diachronic evolution in the last two decades of French higher education, with a particular focus on the bachelor's degree in environmental planning as offered through 17 different B.A. programmes throughout France; the curriculum of the programmes was analysed using a context analysis. The study started in $2004[22,23]$ and was extended in 2021; it is connected to the partnership between territories and education, and in some way to actors and citizenship. Power relations through EE are analysed, taking into account the introduction of ESD at university. Analysis shows that changes in EE have occurred in terms of the movement of degrees towards sustainable development over the last two decades, thus changing access to environmental citizenship. The issue is a much deeper curriculum change, which modifies power relations and knowledge use in environmental citizenship education.

The Hungarian case study is based on document analysis (policy documents, planning documents), on available data, and on six semi-structured interviews conducted with teachers responsible for school gardens (3 interviews), with civic organizers of the School Garden movement ( 2 interviews), and an additional interview with a representative of the state administration. The interviews were transcribed. The interviews were supplemented by transect walking, as a triangulation method. We analysed the interviews using a semiopen coded method to explore the power relations and knowledge forms influencing the development of school gardens.

The Serbian case study is based on analyses of the semi-structured interviews conducted with teachers engaged in the compulsory education system as well a teacher who is the founder of an NGO and who works additionally with children with special interests in environmental problems. Semi-structured interviews were conducted to investigate particular questions about environmental education, knowledge use, and knowledge production in compulsory education of the current country and to give examples of case studies that can contribute to the better understanding of the interaction of knowledge and environmental citizenship behaviour.

The Turkish case study is based on a methodology used by Oral et al. [22]. A questionnaire was prepared to collect the responses of the foreign students from African countries and native Turkish students, who took the "Fundamentals of Sustainable Development" course from the Faculty of Economics and Administrative Sciences; they were asked what they knew about sustainability. The survey asked about the environmental knowledge, thoughts, and behaviours of the international and Turkish students. A study by Uzun and Sağlam [23] cites a questionnaire with 37 questions. The convenience sample method, which is further aided by the Google survey form, was used to identify 50 international and 50 Turkish students, for total at 100 students, at random. Students accessed the forms online for two weeks. For data analysis and interpretation, we used the SPSS 17. 


\section{Results-Country Case Studies}

\subsection{The Hierarchical Power of Project Knowledge over Bottom-Up Managerial Initiatives in} France

The French story of environmental education clearly reflects the consequences of project proliferation, the extent of which is indicated by the emergence of the concept of "projectified society" $[24,25]$. The ongoing conceptual, moral, and financial opposition between experts and key citizens ended with the dominance of the project's practical needs. According to Kovách and Kučerova, project class theory [11], with the emergence of the new social class, involves the substantial changes associated with knowledge use. The practice-oriented project class has a specific approach to using, reflecting on, and producing knowledge. The main goal of the project class is materialistic, and flexibility in managerial and other skills provide vitality for achieving this goal. Kovách and Kučerova concept of the rivalry of two cognitive groups - the project class and the scientists - to define directions of development and control over resources, which may provoke the realignment of knowledge use and the production of knowledge, can be extended to the conflict between project class and key citizen on the basis of the French case. In a hierarchical power network, the benefits of local initiatives weaken and scientific knowledge loses its guiding role.

\subsubsection{Context of Case Study}

In the present paper, we analyse the changes of the role of different types of knowledge in the curriculum of French universities. We focus on the following knowledge types: (i) environmental systems knowledge, (ii) action-related knowledge, and (iii) effectiveness knowledge and its different meanings in the last two decades [4]. The goal of the study is to understand the co-production and power relation between new knowledge by experts and key citizens as central to the idea of a participatory approach towards developing Environmental Citizenship. This analysis is linked to the fact that, in France, environmental citizenship education terminology in not used currently, and EE has gone through various evolutionary stages [26]. Our hypothesis is that these stages are related to knowledge-use changes in environmental citizenship. The first stage is the integration of environmental issues in the educational process, linked to the social movement in France, which focuses on nature and nature conservation. The evolution of the terminology from education related to Education for Sustainable Development is the second stage. It is connected with the international movements for institutional ESD's global expansion, starting with the Bruntlandt report [27] and the decade of ESD (2004-2014) and culminating in the 2030 UNESCO report concerning the 17 SD goals [26]. A third stage involves the shift to Anthropocene education and/or transition education. As an earlier paper presents, the concept of sustainable development is accepted by the different actors in university education and becomes part of the curriculum [28], but that changes the power relations in EE.

\subsubsection{Presentation of the Case: Based on Facts}

The case analyses the curricular diachronic evolution of the last two decades of French higher education. The sample is made up of the curriculum of 17 different bachelor degree programs in environmental planning, distributed throughout France. The method is based on the word occurrence and content analysis collected for 2004 B.A programs, then for 2014 [29,30], and ultimately, 2021. Then, we focus on curriculum changes and their meanings.

Our analysis shows that the presence of ESD brought profound changes at universities in France; thus, we seek to reveal whether this change applied only to curriculum or also to citizenship knowledge use. To do so, we link these elements to the above-described knowledge forms as well as to numbers of interactions between the diplomas and the surrounded territories, especially the personalized territory-based education project, to 
analyse the citizenship competencies. Implementation of SD in higher curriculum comes with local agendas, with communities engaging in them through different approaches. They generate partnerships between universities and local actors through their roles as financers. Then, the educational contents are therefore formalized, in part, around these projects. Thus, we can say that the local translation of public policies of SD will be based on local associations that respond to tenders, and the studies to be performed will be helped by the student body. Both are legitimized by the presumed expertise of faculty members and their institutional presence in the project. In return, the local association (which possesses the application experience of SD approaches) inserts the students in a concrete sustainable development project, valued as a social integration of the university.

We noticed that educational content is turning slowly from environmental to sustainable development studies [31]. Knowledge forms are evolving into hybrid forms [32]. Contents are more oriented toward local partnership entering the curriculum, which can be considered as the evolution of environmental citizenship education.

There was a strong decrease of environmental systems knowledge [33] in the last two decades; this period also showed an increase of action-related knowledge and effectiveness knowledge, which could prove that they are not linked. As noted by SmederevacLalic et al. (2020) [4], (p. 73.) "Education should encompass two types of literacy-ecological literacy and civic literacy". ESD curriculum evolution puts forward a principle of partnership with local territories and the associated sphere [34,35]. This stipulates the idea of educational co-construction and thus curriculum hybridisation. This means that the collaboration between the different actors is involved in the curriculum process of developing guidelines and training content. But it is also strongly framed by imposed international standards. This raises a number of ethical issues related to the educational institution [36] and the legitimacy of the teachings. The authors also formulate the idea of a utilitarian and dominant partnership [37]. We consider this is in some way contrary to the idea of reflective citizenship.

Thus, territorial actions, the autonomy of universities, and project-based teaching push in a multi-stakeholder dynamic and lead to a hybrid curriculum [32]. In this way, ESD is also considered as environmental citizenship education but is frequently linked to controversial issues [38,39]. Two dominant features emerge about the perception of civic engagement and scientific local knowledge appearance and use in the initiative.

The relative absence of scientific knowledge from the educational project was presented in the scientific literature [29]. The reason for this is that these curricula have a behavioural (focused on best practices) and developmentalist (the economic value of knowledge, for instance for tourist interests) focus. We formulate that this could cause changes in learners' relationships to knowledge and promote change in societal logic, but this is still attenuated in France, considered as environmental reflexive citizenship. From an epistemological viewpoint, the aim of most ESD actors in territories is to construct an intermediate reference framework. This could legitimize the choice of teaching and learning contents. Then, the knowledge chosen as a priority is that which seems useful in terms of justifying the social normalization process associated with sustainable development as a political project. The selected knowledge becomes valuable according to its degree of immediate operationality: it mostly underpins practice, which has several consequences. The first one is a form of rejection of more theoretical knowledge. The second one is the lack of knowledge problematization, which goes against the civic educational approaches that aim at promoting deliberative or critical thinking [29] even though they are often formulated in relation to sustainable development. Most of the time, knowledge is, instead, presented as self-evident (common future for instance) and is therefore not discussed. The risk is what is finally excluded is the scientific debate about the uncertain nature of the scientific knowledge that could serve as a reference, leading to relativism. Reduced to its most basic expression, scientific knowledge serves as an alibi, and any confrontation between scientific paradigms is systematically avoided. 
However, this epistemic void is filled by the emergence of content, generally new teachings or presentations of good practices, mostly related to project management. What is considered by few as best practices and included in projects becomes a non-discussed admitted societal practice. Then, life is increasingly conceived in terms of project management - a series of responses to project tenders - with a concomitant emphasis on competitive values and performance. However, this happens to the exclusion of other forms of societal organization. This way of teaching establishes new forms of societal management and new powers of governance. These are both supported by lessons in law and in communication, again without the principles being discussed. From this point of view, the new governance theories have a performative nature (in the sense meant by Callon) [40]; that is to say, they contribute to the creation of the social reality that they purport to explain.

The negation of the distance between the knowledge to be taught (generally recognized as necessary in that it ensures a degree of objectivity) and social practices is, then, a common posture in ESD. This is evidenced by the lesson plans based on examples of ecoefficiency initiatives or social practices such as ways of organizing waste sorting, composting, carpooling, etc. [28,30,41]. By placing emphasis on technical aspects without any critical distance, education could become a technique for the operationalization of procedures. As one of the results, the ability to problematize sustainable development issues, though central to the making of autonomous citizens [38,39], is low, which causes a risk of a normative drift. Teaching becomes training in ethics, which focuses on the 'politically correct' to the detriment of scientific knowledge. The normative drift continues to the point of resulting in the interpenetration of vocational logics and of the private sphere [29]. Schematically speaking, convincing individuals of the need to recycle waste at home is easier than tackling the issue through a reflection on production and on long-term waste management. This negation of the distance between social practices and knowledge crystallizes the debate around a project of normalization that is supposed to be collectively accepted [28], as is evidenced by the adoption (without any serious debate, and strongly oriented towards "best practices") of "green plans" by universities. Indeed, SD conveys an image of collective responsibility in a common world, and anything that refers to it then appears as unquestionably necessary for the construction of a safeguard project meant to avoid the destruction of the planet's ecological balance. This normative stance leads teachers to adopt a relativist approach. In other words, they place more emphasis on socially valued behaviour (waste sorting, for example) than on the scientific knowledge their students would need in order to truly understand the phenomena.

\subsection{School Garden Program in Hungary: Practice and Ideology in Multipolar Power Network}

Scientific and managerial knowledge plays a central role in school garden programs, which are both a site of knowledge production and a site to strengthen environmentally friendly attitudes; thus, they contribute to both science education and environmental education [42]. In the long term, their contribution to food self-provisioning and food sovereignty can play a role also in strengthening environmental citizenship. In addition to the involved teachers, different decision-makers appeared around the school garden program, but the different interests could be harmonized in a multipolar power network that has no central individual or institutional actor with a decisive role. The ministry subsidies the program, and the presidential foundation provides a loose framework that schools and teachers fill with great freedom in content. It is thus an effective system, although its growth is limited and is likely to include schools where the social capital of school children is higher than average; this may be a source of unequal distribution of access to future environmental education [43]. 


\subsubsection{The Hungarian Context}

In the following part of the paper, we present the status and role of school gardens in the Hungarian Kindergartens and elementary schools. As we will show, the activity in the school gardens is an optional activity both for the schools and for the pupils, and consequently is very loosely built into the school curriculum, although there is a state programme to promote such initiatives. In the SWOT [1], we argued that both education for environmental citizenship and environmental education (EE) have a highly unfavourable status in Hungary. The closest subjects to EE and citizenship studies are not among the most important subjects in Hungarian primary (and secondary) education. This represents an additional problem; the subjects linked to the activity of school gardens are also less important (for example environmental education was removed from the curriculum of elementary schools as a result of the latest modifications).

\subsubsection{A Special Field for EE: The School Gardens Program in Hungary}

According to a recent report on the school gardens in Hungary, there were at least 1118 gardens; this means that at least in every fifth Kindergarten or elementary school, there is a school garden. Some are more than 70 years old, but most were founded in the last decade [43]. In the first third of the 20th century, school gardens were a more important part of the school curriculum; however, during the eighties and nineties, their popularity stagnated (https://www.iskolakertekert.hu/index.php/hu/tudastar/orszagosfelmeres; accessed on 6 October 2021). Despite this, the initiative never disappeared, and in the last two decades started to blossom again; each year, several new gardens were established. In the last three years, thanks to a school garden programme, school gardens gained special attention [44]. The programme was initiated in Hungary by the Ministry of Agriculture together with the National Agricultural Chamber, the Foundation for School Gardens, and a local organization of the Caritas Hungary, a catholic aid organization. Since its initiation, 167 school gardens have been established and more than 20,000 students have been involved. The program developed gradually: in 2018, 50 schools, in 2019, 17 schools, and in 2020, 100 schools and Kindergartens gained subsidies; the latter was the first year when proposals from Kindergartens were welcome. As we will see later, there are slight differences among the approaches to the role of school gardens in the curriculum and in the school life between the different actors: the Ministry, Caritas, the Foundation, and the schools. Not all school gardens were able to gain subsidies. Nowadays, the initiative benefits from the strong and clear support of the Agricultural Ministry and from a Foundation, which was established by the president of Hungary.

Only by analysing the introductory and promotional materials of the programme does it become clear that the different actors have different goals related to the programme. The overall aim of the initiative is summarised in the following quotation:

"School gardens teach about openness, patience, responsibility, self-care, raise the attention on healthy food, on jobs related to agriculture and environment. By working in the school gardens, pupils learn the proper and conscious use of the environment, gain basic experiences about sciences and have opportunity to try and practice the materials of the lessons." (homepage)

The above quotation collects most of the motivations behind school gardens. The stakeholders linked to the government, like the Minister of Agriculture, the spokespeople of the government, and the leader of the foundation (a former politician) emphasize that school gardens can increase the environmental consciousness of children, that sustainability issues can be linked to everyday practices, and:

"The president of the Republic of Hungary funded the Blue Planet Foundation to support all local initiatives to show that one can work for sustainability not only theoretically in the schoolbooks and in political speeches but in our everyday life." (politician)

The teachers' aspirations are slightly different, as the quotations below show: 
"It is not compulsory for the children, they can work in the gardens for a year or for four years; we would like to show children that it is a joy" (teacher); "We hear from the colleagues that children are really happy to be outside, they even pick the weeds, and are motivated to go outside, to meet the living environment, and also the teachers are happy to see the pupils in another situation" (organizer of school garden programmes). The teachers interpret the school gardens as a pedagogical tool but also as a method to educate in a broader sense, not only in the sciences, but also attitudes and ethics.

The Caritas has a slightly different approach. They organize different workshops, mostly about practical knowledge on gardening, which are linked to other school activities and to other types of gardening; thus, this supports food self-provisioning of the parents. The main aim of the organization is to build communities around the school, to strengthen schooling, and also to encourage food self-provisioning among poor families.

\subsubsection{Case Study Analysis}

School gardens are mainly organized by one or two enthusiastic teachers in each school, but they must have alliances in the school to engage colleagues and children in the activities. They mainly build on their scientific knowledge, but as the Ministry initiated the programmes and subsidies, managerial knowledge also became important. In addition, as the activity is not compulsory, they also show practical examples, and thus go beyond education. This latter can be important for education for environmental citizenship: through the examples, children learn about responsibility towards the environment, learn about food, etc. School gardens could serve as practical sites of education for environmental citizenship and could be the basis of science classes by showing how the knowledge learned during SE classes could be turned into real experiences. Despite this unique opportunity, as EE and Education for Environmental Citizenship are almost invisible, and SE teachers are often not the same as EE (and Education for Environmental Citizenship) teachers, the link between the subjects remains invisible to the students.

\subsection{Context of EE in Serbia:The Examples of Eco Musketeers in Serbia and Eco School Alliance-The Equality Networks}

\subsubsection{The Serbian Context}

Environmental education and the formation of ways of thinking start in youth, and therefore, the function of educators is significant at all levels (preschool, elementary, secondary, and higher education) in order for the generations to fully participate in preventing and solving the problems of the human environment. EE in Serbia operates within the institutional framework of the education system, but on a voluntary basis, in a network of coordinated actors. Because training is strongly related to the basics of the subjects taught in schools, scientific knowledge is of paramount importance. As schools initiate EE training at the individual discretion of principals, and the participation of educators is also an individual decision, local knowledge can be of particular importance. Within the institutional framework of schools, but also using the benefits of civic self-organization, examples of effective, goal-oriented EE that is attractive to students due to its uniqueness can be created. The cooperation of actors with equal network capital is also particularly suitable for accommodating extracurricular volunteers, as exemplified by the extensive volunteer activity. The challenges are how to maintain the flexibility and openness of current cooperation after a project and how to establish closer links with international organizations.

Environmental Education (EE) started in Serbia at the beginning of the 20th century, as the pupil's oath from 1914 indicates:

"I swear that I will not destroy the trees or treat badly the flowers; I promise that I will not sully the floor in the school and in the house or on the road; I give my word that I will not spoil the fences and apply malfunction to buildings; I will never throw papers or whatever kind of trash on the street; I'll always be courteous: I will defend someone 
else's property how I would like to defend mine; I promise to be an honest and straight citizen."

Since that period, environmental education has been integrated into different curricula and has existed in different types of education, but unfortunately, due to turbulent political and economic circumstances, it was never given priority. Between the two conferences of Rio in 1992 and Johannesburg in 2002, it started to be of national importance and an issue of cooperation of two ministries (Ministry of Education, Science and Technological Development and Ministry of Environmental Protection). However, under the unstable political situation in Serbia, environmental issues never gained important role. Now, EE education is in the shadows, like in the most transitional societies [1]. The problems are faulty technology, enormous construction of different facilities in protected areas for the sake of economic interest, despite consequences for nature and natural resources, traffic, fossil fuels and air pollution, the arms race, military actions, and other effects that distort the natural balance and cause damage to nature.

Education for Environmental Citizenship is not considered by the experts as applicable for a major impact on environmental responsibility. It requires interdisciplinary collaborations to fill knowledge gaps. Environmental values affect education, society, ecological and environmental movements, technological development, and traditions. To ensure the creation of ecological value systems of the young generation, family and the collective contributions are crucial.

Despite the fact that environment and ecology are separate subjects that are not present in compulsory education, ecological contents have been studied from the preschool stage. To what extent environmental content will be presented in the obligatory and optional activities depends on the interests and tendencies of the students, educators, and educational system as a whole. In Serbia, major weaknesses are the lack of understanding of the consequences of their own environmental and social actions and the lack of possibilities to create a participative and motivating learning environment.

In primary school education, environmental content is intertwined through many subjects. The main objective is to create the foundations of environmental issues and to develop awareness about the environment. Besides obligatory education content, there are elective subjects in elementary school education. The subject "Nature and Society" is intended to develop the ability for responsible living by teaching about oneself and about one's own natural and social environment. Ecological content in higher elementary education grades is represented in subjects on natural sciences. Geography covers environmental content extensively. In higher education, the field of environmental education is represented at many universities, which have specialized departments for education in ecology and environmental protection [45].

Active environmental citizenship is a proscribed part of the topic "life in the ecosystem", included from Grade 5 to 8 in the primary school curriculum. Pupils are instructed and recommended to participate in activities such as making bird feeders, participate with the local community in animal feeding actions in the area, etc. New curriculum for biology is developed to have topics that are upgraded to be more complex in each subsequent grade. For example, cells should be covered in ecology, genetics, and evolution. The support of school principals is necessary at all education levels (e.g., for biochemistry, biomathematics, and biophysics).

The biology curriculum is defined by the Law on primary education and the program on primary education established by the Ministry of Education, Science and Technological Development of the Republic of Serbia and the Institute for the Improvement of Education of the Republic of Serbia. The program changes every 4 to 10 years. Teachers who would like to be part of the core group for preparation of the new curriculum apply to do so, and the Ministry selects members of the board according to their references. At present, there are six different publishers for the subject of biology for the Grade 4 in primary school, which has not proven a good solution. Each school is allowed to choose a book from a publisher for their pupils to use. The program that should be covered is the same, but in 
many cases the learning material is slightly different. Subjects in the curriculum are connected in an interdisciplinary way. The idea is to have interdisciplinary overlaps and to respect interdisciplinary competences. One of the 11 interdisciplinary competences is the attitude towards the environment (water, air, and land). Thematic planning and project activities in teaching are the main ideas. One project was, for example, setting up a hotel for insects. The subject of geography contributes in terms of which parts of the world bees and insects live. The subject of technical education involves building houses for insects. Mathematics calculates how much cost is involved in building houses for insects, the budget needed, and space that is optimal. Biology educates students on how the disappearance of bees will lead to the dire consequences. Serbian language deals with the literature (books, poems, and stories) on the issue. Languages translate the project aims to languages learned in the particular school. Music teaches the pupils about songs about the insects. Hotels that were made in the school were donated to different interested stakeholders. Each school has its own development plan according to the curriculum. The school should have different activities related to the environment. However, most the teachers demonstrate minimum engagement in these activities and give few practical activities, which does not motivate children to think and act ecologically in everyday life (Smederevac-Lalić, personal communication, 2021).

\subsubsection{The Case Study}

There are some solid examples of environmental education. "Eco musketeers" was initiated by an NGO funded by an especially motivated teacher who works additionally with children with special interests for environmental problems. Beside activities, they compete in global environmental competitions: "EU school for living planet", "Stars of science", etc. Unfortunately, this kind of education and effort has no reward from the state system in Serbia; even though pupils have success in the competition, there are no special awards in terms of further education or enrolment in high school. However, these positive examples continue in practice and in life, because these children will turn to activities that are the application of what they learned in their youth. For example, the students of a teacher who was motivated to do practical work and extracurricular activities are now successful in various fields where knowledge and skills are practically applied to solve environmental issues: on student has a master's degree in sustainable wind use, one opened a recycling yard, one works as a vegetarian chef, and one is an expert in bio programs in cybernetics (Smederevac-Lalić, personal communication 2021).

Another example of formal education in Serbia in the special field of EE is the Eco School alliance. This is a worldwide program in which 56,000 schools are involved. In Serbia, 130 schools have an eco-school label and have fulfilled the requirements (eco patrols, code, flags, program, etc.). Once a year is project day, and all teachers have to work on the proscribed environmental topic that day, such as climate change issues, for example.

\subsection{The Environmental Education in the Closed, Hierarchical Network of Turkish Higher Education}

EE may appear as an optional subject on offer in higher education in Turkey. A significant part of those interested are foreign students. In a university system organized in a bureaucratic fashion, EE is closely linked to disciplinary departments that are only able to respond to challenges with difficulty. In a closed system of higher education interwoven with power networks and interests, EE is subordinated to disciplinary scientific knowledge, resulting in a loss of openness and topicality. The lower interest of Turkish university students is also likely to be a consequence of this. 


\subsubsection{Context of EE in Turkey}

Environmental Education (EE) is not a subject that is commonly taught to students in Turkish higher education institutions. In primary and secondary education institutions, rather than universities, EE is often offered to students at a basic level [46-48].

Regardless of its obscurity, several universities offer this subject as a course. At Istanbul Aydin University (IAU), for example, university elective courses such as Environmental Education and Fundamentals of Sustainable Development are available to students. With 35,999 students enrolled in 2018-2019, including about 6000 foreign students, IAU is one of Turkey's 73 Foundation Universities [23]. In addition, Turkey has 84 private universities and 109 public universities [49].

\subsubsection{The Case of Turkish Tertiary Education}

Several Turkish universities have fundamentals of sustainable development and environmental education courses in their EE programs for undergraduate students. These courses do not take an interdisciplinary approach and do not address current environmental issues like nature-based solutions (NBS) and responses to environmental problems as well as circularity perspectives. Only the Fundamentals of Sustainable Development course at IAU covers these topics in the course syllabus [50] .

The Environmental Education course is offered as an elective university course for the students. Students from the Faculty of Engineering take this course as an elective course. The course's European Credit Transfer System (ECTS) credit is 3.00, and courses are carried out in a face-to-face training model. English is the teaching medium of the course, and the course aims to increase students' level of knowledge of environmental issues. Current environmental science literature was followed in an interdisciplinary manner to prepare the course syllabus [50].

The Fundamentals of Sustainable Development course is also offered as an elective course. The ECTS of the course is 3.00, and it is an in-person course. English is the teaching medium of the course, and the course aims to teach sustainability perception. For this reason, the current environmental science literature was followed under an interdisciplinary structure while preparing the course syllabus. For instance, nature-based solutions and circularity assessments of environmental problems are two of the course topics in the course syllabus [50].

The majority of students enrolled in these courses at IAU are international students. For example, the Fundamentals of Sustainable Development course is offered as an elective to 10 departments in the Faculty of Economic and Administrative Sciences. International students account for more than half of the students enrolled in these departments' courses. The Environmental Education course is also given to the students of the Faculty of Engineering. Students enrolled in all English departments of this faculty take this course as an elective.

The most recent literature, particularly on environmental sciences, was used to prepare the curricula for these courses. Furthermore, the literature published for projects such as H2020-funded research networks COST CA 17133 "Implementing nature-based solutions for creating a resourceful circular city" and CA 16229 European Network for Environmental Citizenship (ENEC), for the respective topics of nature-based solutions and circularity, was used. Moreover, the overall curriculum of these courses is related to an interdisciplinary perspective and a method of evaluation related to other subjects. As for the relation to the knowledge of the students and instructors, students were more involved as they observe current issues in the course curriculum rather than classic and familiar environmental problems. As a result, environmental concerns have become more prominent in people's minds. The method used in this case study is inspired by Oral et al. [50], who studied environmental education as well as citizenship understanding and action among university engineering students. IAU students who took these classes were asked to complete an online survey, and the results were compared to those for students 
from another university. Similarly, several questions were posed to IAU students enrolled in the Environmental Education and Fundamentals of Sustainable Development course online, and their responses were carefully analysed by basic statistics. Since this is an elective course, various faculty members teaching it in different semesters had to do extra study on some of the topics discussed in the program.

A survey conducted among the participants of a course at the Faculty of Engineering on Environmental Education found that the knowledge of the students significantly grew by the end of the semester on circularity and nature-based solutions. It was observed that 29 of 30 students gave the correct answers to questions about NBSs and sustainability. These students will act as forerunners, as examples of environmentally conscious members of their communities. Thanks to their education, they are able to act responsibly and find solutions to the local environmental problems within their own community.

Stakeholders other than students are also involved in the courses. For example, in a factory that his family owned and ran, a student enrolled in the Fundamentals of Sustainable Development course chose to use the waste management and circular economy techniques taught in class. As a result, the student was able to use the production facilities to integrate the important aspects of the topic that he learned during the lecture.

\section{Discussion}

The Hungarian case shows on the one hand how a traditional school practice, the school gardens, gains a new role after being accepted and supported by a government initiative and also how it fails to become integrated into formal education and create a link between the different subjects and everyday life. It also fails to link the otherwise emphasized issue of food sovereignty to environmental education; thus, it cannot be a stepping stone for education on environmental citizenship. As we showed, school gardens are not part of formal education, and the initiatives are mainly based on the enthusiasm of the teachers leading the gardens; it also does not help the integration of science education, environmental education, or education for environmental citizenship.

As we presented above, in Serbia, environmental education and education for environmental citizenship is poorly integrated into formal education, similar to the Hungarian case. Real activism is the result of rare individuals: teachers, pupils, parents, or sometimes even ordinary citizens who complain about local environmental problems. The activities in formal education mostly depend on a school director's affinity to allow and motivate teachers to enrich and broaden the curriculum with action-related environmental behaviour and activities. Despite the fact that EE is present in a modest way in the curriculum from the youngest ages, throughout the whole education system, knowledge and concrete actions usually come from individuals and/or the non-governmental sector, citizens' associations that bring together activists, and people who are aware of environmental problems.

The Turkish case showed that although environmental education and education for environmental citizenship are also not included in the main stream issues of the curriculum of higher education, they are still present and are taught by different departments. The lack of systematic curriculum also leads to a certain neglect of the issue.

The French case shows that ESD causes important value conflicts that lead to different points of view concerning citizenship and civic engagement. In some way, the role of knowledge sharing and community learning could have virtue, but this is considered in France by some researchers as a controversial issue [30]. Given the context, they consider that associative competencies and projects from local territories engage local ESD in two very specific dominant forms in France, which could be very normative. This could be contested in higher education, as can be seen in the different curricula and researchers' positions in education for sustainable development [28]. The first and most widespread is ecoresponsibility (e.g., sorting waste, energy conservation, and car sharing), a result of normative citizen learning. The second is the formalized project area; this can be seen as a utilitarian response to sustainable development. It is based on different forms of technical training: spatial 
planning, tourism, management, community development, agriculture in ESD, etc. Thus, if there is more citizenship education in curriculum design, there is also more uncertainty concerning the quality of citizenship education (loss of environmental systems knowledge) and problems of relativism of the knowledge taught.

Table 1 allows for a comparison of individual cases, showing how complex values, actors, and interests influence the use of knowledge in environmental citizenship. The table also depicts the diversity of institutional forms, knowledge types, the role of power in the different initiatives, and the different variations in citizenship types. As Table 1 shows, both local and scientific knowledge are important in the French, Hungarian, and Serbian cases, while only scientific knowledge is relevant in the Turkish case. Managerial knowledge seems to be important only in the Hungarian case.

Table 1. Dimensions of knowledge use and power in environmental citizenship.

\begin{tabular}{|c|c|c|c|c|}
\hline Context & French & Hungarian & Serbian & Turkish \\
\hline Type of knowledge & $\begin{array}{l}\text { hybrid: scientific and local } \\
\text { knowledge vs. managerial } \\
\text { knowledge }\end{array}$ & $\begin{array}{c}\text { local knowledge, scientific } \\
\text { knowledge, managerial } \\
\text { knowledge }\end{array}$ & $\begin{array}{l}\text { scientific knowledge, } \\
\text { local knowledge }\end{array}$ & scientific knowledge \\
\hline Organisational form & $\begin{array}{l}\text { higher education (technic } \\
\text { of operationalizing) tem- } \\
\text { porary project organisa- } \\
\text { tion, NGO }\end{array}$ & $\begin{array}{l}\text { Kindergarten and primary } \\
\text { schools }\end{array}$ & $\begin{array}{l}\text { environmental education in } \\
\text { schools } \\
\text { foundations, NGO }\end{array}$ & higher education \\
\hline Key actors & $\begin{array}{l}\text { universities partnership } \\
\text { with local actors; manage- } \\
\text { rial project class }\end{array}$ & $\begin{array}{l}\text { teachers \& civic organiza- } \\
\text { tions, ministry (as providers } \\
\text { of financial support) }\end{array}$ & $\begin{array}{l}\text { principals, educators, activ- } \\
\text { ists, volunteers }\end{array}$ & $\begin{array}{l}\text { teachers and scientists, uni- } \\
\text { versity and state administra- } \\
\text { tion }\end{array}$ \\
\hline Basic values & $\begin{array}{l}\text { ethical, sustainability is- } \\
\text { sues-effectiveness issues }\end{array}$ & $\begin{array}{l}\text { ethical, sustainability, volun- } \\
\text { teering-environmental con- } \\
\text { sciousness }\end{array}$ & $\begin{array}{l}\text { ecological, ethical, sustaina- } \\
\text { bility, environmentalism }\end{array}$ & $\begin{array}{c}\text { ecological, scientific, organi- } \\
\text { zation, institutionalization, } \\
\text { controllability } \\
\end{array}$ \\
\hline $\begin{array}{l}\text { Individual and/or insti- } \\
\text { tutional interest }\end{array}$ & $\begin{array}{c}\text { social normalisation- } \\
\text { project effectivity }\end{array}$ & $\begin{array}{l}\text { pedagogical, environmental } \\
\text { enlightenment }\end{array}$ & $\begin{array}{l}\text { environmental conscious- } \\
\text { ness and responsibility net- } \\
\text { working, fund raising, insti- } \\
\text { tutionalisation, sustainable } \\
\text { development }\end{array}$ & $\begin{array}{l}\text { educational, institutional/ } \\
\text { bureaucratic }\end{array}$ \\
\hline Power network & $\begin{array}{c}\text { top-down, controlling, po- } \\
\text { litical project }\end{array}$ & ancillary partnership & cooperating and inclusion & top-down \\
\hline Type of citizenship & participative & $\begin{array}{l}\text { participative and socially re- } \\
\text { sponsible }\end{array}$ & $\begin{array}{c}\text { personally responsible and } \\
\text { participative }\end{array}$ & personally responsible \\
\hline
\end{tabular}

In terms of organizational form, while the French and Turkish case studies present similarities, there is no similarity among the other two countries. NGOs, on the other hand, form the common points of the French and Serbian cases. A closer examination of the other criteria in the Table reveals that the case studies of the four countries have little in common. Key actors and individual and/or institutional interests can be given as examples of this. Analysing the type of citizenship, we found that the French and Hungarian cases show a participative, while the Serbian and Turkish cases a personally responsible, citizenship model.

Further quantitative research would be necessary to gain generalizable results on the role of the different factors influencing the use of the different knowledge forms and the effects of power relations in education for environmental citizenship.

\section{Conclusions}

The presented case studies from the four different countries helped us to better understand the knowledge use in environmental education and in education for environmental citizenship. Among the drivers of environmental education, bottom-up NGOs or committed individuals play a particularly advanced role. In most cases, they are initiators and pioneers who 
are able to activate several types of knowledge, such as environmental systems knowledge, action-related knowledge, managerial knowledge, effectiveness knowledge, and above all, scientific knowledge. Compared to formal education, environmental education can apply hybrid types of knowledge, even if it is realized within the school system. The knowledge of activation, involvement, and persuasion is clearly a strength and advantage that is not present in other forms of education. An evolutionary approach is the key to the success of educational practices, nourished by scientific knowledge and always oriented toward rapidly changing practice.

In the activities of temporary organizations, or in the practices of school courses considered as additional subjects, the transfer of knowledge that accepts complexity and variability as a goal can necessarily conflict with the knowledge monopoly arising from the interests of bureaucratic organizations (e.g., school systems, project management). The novelty of our joint study of knowledge use and power relations highlights that, from an organizational point of view, without coordinating the activities of temporary organizations, volunteers, and bureaucratic organizations in new ways, the extension of the essence of environment citizenship can be damaged. Case studies from four countries show that the bureaucratic governmental, EU, educational, and project organizations mostly override and limit the benefits of bottomup initiatives, the complex, flexible use of knowledge, and mobilization capacity. The message of our work is that achieving environmental citizenship cannot be without coherence between the bottom-up and bureaucratic organizations.

This paper collected experiences from European and inclusiveness target countries in the context of education for environmental citizenship at different levels, from preschool to tertiary education. The common conclusion from all of the countries involved in the survey is the need for environmental citizenship education, despite the differences in environmental perceptions or political and economic contexts. Education for environmental citizenship is promoted at different multidisciplinary educational levels and depends on social development. The collaboration between countries through international projects has a significant impact in promoting environmental citizenship and sustainable development at all levels.

Author Contributions: Conceptualization, I.K. and B.G.M.; methodology, I.K. and B.G.M.; validation, all authors; formal analysis, all authors; resources, all authors; writing-original draft preparation, all authors; writing - review and editing, I.K. and B.G.M. All authors have read and agreed to the published version of the manuscript.

Funding: This research was funded by the European Cooperation in Science and Technology COST Action CA16229 “European Network for Environmental Citizenship (ENEC)”. Boldizsár Megyesi was supported by the Bolyai János Post-doctoral Stipendium of the Hungarian Academy of the Sciences. The research was funded by the NKFI 132676.

Institutional Review Board Statement: Not applicable.

Informed Consent Statement: Informed consent was obtained from all subjects involved in the study.

Conflicts of Interest: The authors declare no conflict of interest.

\section{References}

1. Hadjichambis, A.C.; Reis, P.; Paraskeva-Hadjichambi, D. (Eds.) European SWOT Analysis on Education for Environmental Citizenship; Instituto de Educação, Universidade de Lisboa: Lisbon, Portugal, 2019; ISBN 978-9963-9275-6-2.

2. Dobson, A. Citizenship and the Environment; Oxford University Press: Oxford, NY, USA, 2003; ISBN 978-0-19-925843-7.

3. Balundè, A.; Perlaviciute, G.; Truskauskaitè-Kunevičienè, I. Sustainability in Youth: Environmental Considerations in Adolescence and Their Relationship to Pro-Environmental Behavior. Front. Psychol. 2020, 11, 582920, doi:10.3389/fpsyg.2020.582920.

4. Smederevac-Lalic, M.; Finger, D.; Kovách, I.; Lenhardt, M.; Petrovic, J.; Djikanovic, V.; Conti, D.; Boeve-de Pauw, J. Knowledge and Environmental Citizenship. In Conceptualizing Environmental Citizenship for 21st Century Education; Hadjichambis, A.C., Reis, P., Paraskeva-Hadjichambi, D., Činčera, J., Boeve-de Pauw, J., Gericke, N., Knippels, M.-C., Eds.; Springer International Publishing: Cham, Switzerland, 2020; pp. 69-82, ISBN 978-3-030-20249-1.

5. Bruckmeier, K.; Tovey, H. Knowledge in Sustainable Rural Development: From Forms of Knowledge to Knowledge Processes. Sociologia Ruralis 2008, 48, 313-329, doi:10.1111/j.1467-9523.2008.00466.x. 
6. Rahman, A. Development of an Integrated Traditional and Scientific Knowledge Base: A Mechanism for Accessing, Benefit-Sharing and Documenting Traditional Knowledge for Sustainable Socio-Economic Development and Poverty Alleviation; UNCTAD: Geneva, Switzerland, 2000; p. 30.

7. Folke, C. Traditional Knowledge in Social-Ecological Systems. Ecol. Soc. 2004, 9, 7.

8. Janssen, M.A.; Anderies, J.M.; Ostrom, E. Robustness of Social-Ecological Systems to Spatial and Temporal Variability. Soc. Nat. Resour. 2007, 20, 307-322, doi:10.1080/08941920601161320.

9. Bodorkós, B.; Mihók, B.; Bela, G.; Gálhidy, L. Local People and the Changes of Local Environment in the South-Borsod Region. In Proceedings of the 26th European Society for Rural Sociology Congress, Aberdeen, Scotland, 18-21 August 2005.

10. Kovach, I.; Kucerova, E. The Project Class in Central Europe: The Czech and Hungarian Cases. Sociologia Ruralis 2006, 46, 3-21, doi:10.1111/j.1467-9523.2006.00403.x.

11. Kovách, I.; Kučerova, E. The Social Context of Project Proliferation-The Rise of a Project Class. J. Environ. Policy Plan. 2009, 11, 203-221, doi:10.1080/15239080903033804.

12. Boltanski, L.; Chiapello, E. The New Spirit of Capitalism; Verso: Brooklyn, NY, USA, 2005; ISBN 978-1-85984-554-7.

13. Schäfer, T.; Kieslinger, B. Supporting Emerging Forms of Citizen Science: A Plea for Diversity, Creativity and Social Innovation. J. Sci. Commun. 2016, 15, 1-12.

14. Levinson, R.; Paraskeva-Hadjichambi, D.; Bedsted, B.; Manov, B.; Hadjichambis, A.C. Political Dimensions of Environmental Citizenship. In Conceptualizing Environmental Citizenship for 21st Century Education; Environmental Discourses in Science Education; Hadjichambis, A.C., Reis, P., Paraskeva-Hadjichambi, D., Činčera, J., Boeve-de Pauw, J., Gericke, N., Knippels, M.-C., Eds.; Springer International Publishing: Cham, Switzerland, 2020; Volume 4, pp. 17-28, ISBN 978-3-030-20248-4.

15. Kymlicka, W. Contemporary Political Philosophy: An Introduction, 2nd ed.; Oxford University Press: Oxford, NY, USA, 2002; ISBN 978-0-19-878274-2.

16. Etzioni, A. Communitarianism Revisited. J. Political Ideol. 2014, 19, 241-260, doi:10.1080/13569317.2014.951142.

17. Dobson, A. Green Political Thought, 4th ed.; Routledge: London, UK, 2007; ISBN 978-0-415-40351-1.

18. Johnson, L.; Morris, P. Towards a Framework for Critical Citizenship Education. Curric. J. 2010, 21, 77-96, doi:10.1080/09585170903560444.

19. Csurgó, B.; Kovách, I.; Kučerová, E. Knowledge, Power and Sustainability in Contemporary Rural Europe. Sociologia Ruralis 2008, 48, 292-312, doi:10.1111/j.1467-9523.2008.00461.x.

20. Kvale, S. Ten Standard Objections to Qualitative Research Interviews. J. Phenomenol. Psychol. 1994, 25, $143-176$.

21. Yin, R.K. Case Study Research: Design and Methods, 4th ed.; Applied Social Research Methods; Sage Publications: Los Angeles, CA, USA, 2009; ISBN 978-1-4129-6099-1.

22. Oral, H.V.; Eren, Ö.; Yay, A.S.E.; Saygın, H. Environmental Citizenship Perception and Behavior among University Engineering Students in the Marmara Region of Turkey. Environ. Dev. Sustain. 2021, 23, 3638-3652, doi:10.1007/s10668-020-00736-8.

23. Uzun, N.; Sağlam, N. Orta öğretim öğrencileri için çevresel tutum ölçeği geliştirme ve geçerliliği. Hacettepe Üniversitesi Ĕ̆itim Fakültesi Dergisi 2006, 30, 240-250.

24. Lundin, R.A.; Söderholm, A. Conceptualizing a Projectified Society Discussion of an Eco-Institutional Approach to a Theory on Temporary Organisations. In Projects as Arenas for Renewal and Learning Processes; Lundin, R.A., Midler, C., Eds.; Springer: Boston, MA, USA, 1998; pp. 13-23, ISBN 978-1-4613-7605-7.

25. Sjöblom, S.; Godenhjelm, S. Project Proliferation and Governance-Implications for Environmental Management. J. Environ. Policy Plan. 2009, 11, 169-185, doi:10.1080/15239080903033762.

26. Slimani, M.; Barthes, A.; Lange, J.-M. Les questions environnementales au miroir de l'évènement Anthropocène: Tendance politique et hétérotopie éducative. Le Télémaque. Philosophie, Education, Société 2020, 2, 75-88, doi:10.3917/tele.058.0075.

27. World Commission on Environment and Development. Our Common Future; Oxford Paperbacks; Oxford University Press: Oxford, NY, USA, 1987; ISBN 978-0-19-282080-8.

28. Barthes, A.; Lange, J.-M. Researchers' Positions and Construction of Curricula of Education for Sustainable Development in France. J. Curric. Stud. 2018, 50, 96-112, doi:10.1080/00220272.2017.1347716.

29. Barthes, A.; Alpe, Y. Les Éducations À : Une Remise En Cause de La Forme Scolaire ? Carrefours de l'éducation 2018, 1, $23-27$.

30. Legardez, A.; Simonneaux, L. Développement Durable et Autres Questions D'actualité; Educagri: Dijon, France, 2011; ISBN 978-284444-841-5.

31. Barthes, A.; Alpe, Y.; Bader, B. Questions and Positions on Education for Sustainable Development at University in France: Example of Short Professional Cycles. Environ. Educ. Res. 2013, 19, 269-281, doi:10.1080/13504622.2012.690854.

32. Barthes, A.; Lange, J.-M.; Tutiaux-Guillon N. Dictionnaire Critique Des Enjeux et Concepts Des "Éducations à"; L'Harmattan: Paris, France, 2017; ISBN 978-2-343-12678-4.

33. Barthes, A. Quels Outils Curriculaires Pour Des “Éducations à" Vers Une Citoyenneté Politique? Éducations 2017, 17, 25-40.

34. Corcoran, P.B.; Osano, P.M. (Eds.) Young People, Education, and Sustainable Development: Exploring Principles, Perspectives, and Praxis; Wageningen Academic Publishers: Wageningen, The Netherlands, 2009; ISBN 978-90-8686-093-7.

35. Villemagne, C. L'éducation Relative à l'environnement En Contexte d'alphabétisation Des Adultes: Quelles Dimensions Critiques? L'éducation Relative à L'environnement 2008, 7, 1-15 doi:10.4000/ere.3143.

36. Bruxelle, Y. Le Partenariat, Entre Réticences et Fascination : Quels Questionnements Éthiques Pour l'institution Scolaire ? L'éducation Relative à L'environnement 2007, 6, 1-17 doi:10.4000/ere.3962. 
37. Barthes, A.; Champollion, P. Éducation Au Développement Durable et Territoires: Évolution Des Problématiques, Modification Des Logiques Éducatives et Spécificité Des Contextes Ruraux. L'éducation Relative à L'environnement 2012, 10, 2-19 doi:10.4000/ere.1049.

38. Levinson, R. Science Education and Democratic Participation: An Uneasy Congruence? Stud. Sci. Educ. 2010, 46, 69-119, doi:10.1080/03057260903562433.

39. Levinson, R. SAQs as a Socio-Political Programme: Some Challenges and Opportunities. Sisyphus J. Educ. 2017, 5, 25-39, doi:10.25749/SIS.11845.

40. Barraud de Lagerie, P. Michel Callon, L'emprise Des Marchés. Comprendre Leur Fonctionnement Pour Pouvoir Les Changer. Sociologie du Travail 2020, 62, 504, doi:10.4000/sdt.30493.

41. Lange, J.-M.; Kebaïli, S. Penser l'éducation au temps de l'anthropocène: Conditions de possibilités d'une culture de l'engagement. Éducation et socialisation. Les Cahiers du CERFEE 2019, 51,1-14, doi:10.4000/edso.5674.

42. Halbritter, A.A.; Szunyogh, L.; Balogh, I.; Gaál, J.E. Napóra és társai: Környezeti és vizuális nevelés az iskolaudvaron. In Elmélet és Gyakorlat a Neveléstudományok és Szakmódszertanok Köréből; International Research Institute s.r.o.: Komárno, Slovakia, 2018; ISBN 978-80-89691-52-4.

43. Jákli, E. Iskolás gyermekek szabadtér-használati preferenciái az iskolakertekben. J. Appl. Tech. Educ. Sci. 2020, 10, 63-81, doi:10.24368/JATES.V10I1.146.

44. Kövecsesné Gösi, V.; Lampert, B. A Környezetpedagógia Gyakorlata a Tanítóképzésben. J. Appl. Tech. Educ. Sci. 2018, 8, 36-54, doi:10.24368/JATES.V8I2.37.

45. Lenhardt, M.; Smederevac-Lalic, M.; Radovic, V. Short Country Report SERBIA SWOT Analysis of Education for Environmental Citizenship. In European SWOT Analysis on Education for Environmental Citizenship; Hadjichambis, A.C., Reis, P., ParaskevaHadjichambi, D. Eds.; Instituto de Educação, Universidade de Lisboa: Lisbon, Portugal, 2019; pp. 246-260.

46. AkengiN, H.; İBrahiMoğlu, Z. Ilköğretim programinda çevre eğitimi. Marmara Coğrafya Dergisi 2015, 0, 106, doi:10.14781/mcd.55616.

47. Akınoğlu, O.; Sarı, A. Ilköğretim programlarinda çevre eğitimi. Marmara Üniversitesi Atatürk Ĕ̆itim Fakültesi Ĕ̆itim, Bilimleri Dergisi 2013, 5-29.

48. Can, E. Okul Öncesi Eğitim Öğretmenlerinin Okul Yönetimine Katılımlarının İncelenmesi. Dicle Üniversitesi Ziya Gökalp Ĕ̆itim Fakültesi Dergisi 2017, 30, 525-542, doi:10.14582/DUZGEF.791.

49. Council of Higher Education (CoHE) 2020. Available online: https://www.yok.gov.tr/Sayfalar/Haberler/2020/hedef-odakliuluslararasilasma.aspx (accessed 6 May 2021).

50. İstanbul Aydın University (IAU) 2021. Available online: https://www.aydin.edu.tr/tr-tr/akademik/yuksekokullar/yabancidiller/mutercim-tercumanlik-ingilizce/Pages/Ders-Plan\%C4\%B1.aspx?dID=13817 (accessed on 5 February 2021). 